\title{
Colonial wildlife conservation and the origins of the Society for the Preservation of the Wild Fauna of the Empire (1903-1914)
}

\author{
David K. Prendergast and William M. Adams
}

\begin{abstract}
Fauna \& Flora International (FFI) celebrates its centenary in 2003. It was founded as the Society for the Preservation of the Wild Fauna of the Empire (SPWFE) in London in 1903. This paper analyses the events, people, and debates behind its formation and early development. It discusses why the Society was formed, how it worked, and what its main concerns were. It considers the nature and success of the Society's work from 1903 to 1914 in influencing the British Colonial Office's policy on issues such as game reserves, hunting and wildlife clearance for tsetse control in Africa.
\end{abstract}

The SPWFE drew together an elite group of colonial administrators, hunters and other experts on game in Africa, and was effective in lobbying the Colonial Office about preservation. Many of its concerns, and ideas about how to address them, are similar to those that are current today, a century after its establishment.

Keywords Colonial conservation, colonial policy, conservation history, Fauna \& Flora International, game reserves, hunting, preservation.

\section{Introduction}

Fauna \& Flora International (FFI) celebrates its centenary in 2003, claiming to be the world's oldest international conservation organization. It was founded as the Society for the Preservation of the Wild Fauna of the Empire (SPWFE, hereafter the Society) in 1903. The Society dropped the word "wild" from its title after the First World War and then shortened it further to the Fauna Preservation Society (FPS) in 1950 (Fitter \& Scott, 1978). Since then, the Society has undergone two further name changes as its aims have broadened, becoming the Fauna \& Flora Preservation Society (FFPS) in 1980 and Fauna \& Flora International (FFI) in 1995.

Research on the history of wildlife conservation outside America and Western Europe, and particularly in Africa, emphasizes its colonial roots, arguing that the ideas dominant in the early part of the twentieth century persist to the present day (Anderson \& Grove, 1987; MacKenzie, 1988; Neumann, 1998). The history of European colonial environmental concern is deep and complex. There was growing awareness of the problem of deforestation from the eighteenth century, notably on the islands of the Indian Ocean and the Caribbean. This

David K. Prendergast Department of Social Anthropology, University of Cambridge, Free School Lane, Cambridge, CB2 3RF, UK.

E-mail:dkp20@cam.ac.uk

William M. Adams (Corresponding Author) Department of Geography, University of Cambridge, Downing Place, Cambridge, CB2 3EN, UK.

E-mail:wa12@cam.ac.uk

Received 5 February 2003. Revision requested 26 February 2003. Accepted 10 March 2003 became linked to beliefs about links between climate change and drought, and led to the establishment of measures for forest protection (Grove, 1992, 1995, 1997, 1998). Imperial forestry, including ideas of rational resource use, was well established in India by the midnineteenth century (Barton, 2002), as well as in the South African Cape.

Concern for wildlife preservation was caused by the fears of colonial hunters of the extinction of species and the depletion of stocks of wildlife or game animals through over-hunting, particularly in the Cape (MacKenzie, 1987, 1988). Hunting was important to elite British society in the Victorian period, and was central to its replication across the Empire (MacKenzie, 1988). The fascination with sport hunting was also shared by wealthy American industrialists (Jacoby, 2001). The near-extinction of the American bison Bison bison epitomized the effects of unbridled hunting. In addition to the importance of hunting, it is argued that in the colonial era European observers saw the wildlife-rich landscapes of Africa as some kind of 'lost Eden' in need of protection and preservation (Neumann, 1995). Arguably, ideas about wildlife conservation in British colonial Africa, particularly the classic model of game regulations and reserves, were borrowed from the world of English aristocratic rural estates even as the institution died out in England (Neumann, 1996, 1997, 1998).

The SPWFE was established at a critical moment in the formalization of colonial wildlife conservation. Neumann sees it as emblematic of the conservationist ideas of the twentieth century colonial enterprise as a whole. This paper analyses the Society's foundation, and the conservation issues that were of contemporary 
concern in its early work. Chief among these were the idea of reserves for game, the problem of over-hunting and tsetse fly. The period covered here ends in 1914, a natural break, for the Society's work was much reduced for the duration of the First World War.

\section{Why the Society was founded}

The central character in the first decades of the Society was Edward North Buxton. By 1903 he had already demonstrated commitment to conservation in the UK. He was the grandson of Sir Thomas Fowell Buxton, the leader of the anti-slavery movement, and his father bought house and land in Epping Forest in 1851. Never afraid of confrontation, E.N. Buxton and his brother risked social opprobrium by siding with local woodloppers against landowners who wished to enclose Epping Forest, as had been done at Hainault (Addison, 1991). Buxton was a leading figure in the Commons Preservation Society, founded in 1865 to fight enclosure of areas such as Hampstead Heath and Wimbledon Common (Sheail, 1976). He was instrumental in bringing in the Corporation of the City of London against enclosure (the Buxtons owned a family brewery in Spitalfields). In writing of the campaign in 1923, Buxton wrote that "a truer and juster view of the needs and rights of the public began to prevail" (Buxton, 1923, p. 15). In 1875 , the Corporation began to purchase manors within Epping Forest, and the forest was finally vested in the Corporation, under the Epping Forest Act of 1878, to be used for public open space. Buxton and his elder brother were Verderers for much of the next half century. Buxton remained committed to conservation in Britain throughout his life, among other things purchasing Hatfield Forest in Essex on his deathbed for the National Trust (SPFE, 1924).

Buxton was a hunter and, in the words of his obituary, "an ardent preserver of game" who held strongly that hunting "must not be done in such a way as to endanger the existence or seriously diminish the stock of game" (SPFE, 1924, p. 23). At the time of the formation of the SPWFE, he had made visits to British East Africa and Somaliland, hunting and taking photographs. He had published accounts of these expeditions, illustrated with numerous photographs of birds and mammals, just before the SPWFE was created (Buxton, 1898, 1902). He had travelled in "the Kenia-Kilimanjaro plateau", and in the Sudan, "two of the best game districts remaining in Africa" (Buxton, 1902, p. 115), and he had formed clear views of the chief challenges to conservation and what action was needed to confront them. In addition to its account of travel and natural history, his 1902 book Two African Trips sought a deliberate engagement with British colonial policy.
The chief problem that Buxton perceived was a failure of "true sportsmanship" in hunting by Europeans (Buxton, 1902, p. 115). The disappearance of game (by which he meant almost all large mammals, especially antelope, but including carnivores, elephant Loxodonta africana, rhinoceros and hippopotamus Hippopotamus amphibius) was the result of "reckless shooting" of excessive numbers of animals (Buxton, 1902, p. 115). It was in the interests of the real sportsman, and particularly resident officers of colonial administrations, that game should be "played fair". It was "bloodthirstiness", where "an otherwise sane man runs amuck" (Buxton, 1902, p. 116), and not "honest sport", which was responsible for the depletion of so many game fields. Game should be viewed as "a precious inheritance of the empire, something to be guarded like a unique picture", "something which may easily be lost, but which cannot be replaced" (Buxton, 1902, p. 116). The arrival of the railway and other forms of communication were a serious threat to Kenyan game in particular. The decimation of the dense herds of game on the South African veldt showed what might happen, where "a paradise of varied life, which is now irretrievably lost through the carelessness and wastefulness of white men" (Buxton, 1902, p. 117). Even if game preservation cost money, Buxton urged that "all necessary sacrifices will be made to preserve them while there is yet time" (Buxton, 1902, p. 117).

The context for Buxton's arguments was the International Conference of the African colonial powers (Germany, France, Britain, Portugal, Spain, Italy and the Belgian Congo) in London, resulting in the 1900 Convention for the Preservation of Animals, Birds and Fish in Africa. Concern about the extinction of game in Africa was well established at the turn of the nineteenth century, particularly because of experiences in South Africa (MacKenzie, 1988). The Cape Act for the Preservation of Game was passed in 1886, and extended to the British South African Territories in 1891 (Grove, 1987; MacKenzie, 1987). In 1892 the Sabie Game Reserve was established in the Transvaal (Stevenson-Hamilton, 1952; Carruthers, 1995). The British Foreign Office drew attention to the need for Game Regulations in African territories in 1891. In 1896 a decree was passed in German East Africa under its Governor, Hermann von Wissmann establishing game reserves and a licensing system. Game regulations were promulgated in Uganda and the East African Protectorate in 1897 (Cd. 3189, 1906; Beachey, 1967; MacKenzie, 1988).

In 1902 Buxton noted that the Foreign Office was "thoroughly alive" to the question of preservation, but provisions were far from perfect (Buxton, 1902, p. 118). Game preservation regulations enacted in British Central Africa, British East Africa and Uganda, and (by the India Office) in Somaliland typically imposed an expensive 
licence on travellers wishing to hunt, and a cheaper one for residents and officials. In some cases they also limited the numbers of species such as rhinoceros and elephant that could be killed. There had also been some progress with the establishment of game reserves, for example in Kenya.

The Convention sought to strengthen and standardize game laws across colonial Africa. Signatories agreed to establish a selective list of species in danger of extinction that should be protected from hunting, (as should immature animals and breeding females), to limit the sale of elephant tusks of less than $11 \mathrm{lbs}$, and to establish "adequate reserves and protect them from encroachment" (Buxton, 1902, p. 119). In British territories, reserves had been set aside in Sudan, Kenya, Uganda, British Central Africa (a small reserve in what is now Malawi, at Elephant Marsh, unfortunately already without elephants) and Somaliland. Territories had established schedules of protected species (typically including the giraffe Giraffa camelopardalis, eland Taurotragus spp. and buffalo Syncerus caffer as they were thought to have been brought to near extinction by the rinderpest panzootic, although special protection for eland and buffalo was later removed once numbers improved), and larger and slow-breeding species whose breeding females and young should be preserved (e.g. rhinoceros, hippopotamus, and greater kudu Tragelaphus strepsiceros). In addition, licences set a limit on the numbers of each species that could be killed, and demanded a list of what had been killed when the licence expired. This regulation clearly irked some, but Buxton dismissed objections with revealing ferocity: "the legitimate sportsman has no reason to fear it, and the mere butcher should be gibeted (sic)" (Buxton, 1902, p. 121).

Buxton's book set out a critique of British conservation policy, and an agenda for future action. The key focus of his attention was the provision of game reserves. Buxton's critique was twofold. First, he criticised their location, pointing out that the areas selected at first "were not always chosen with sufficient knowledge or regard to the surroundings conditions and the need of the game" (Buxton, 1902, p. 121). Secondly, he criticised their management, and particularly the prevalence of hunting by colonial officers. The purpose of the reserves as 'sanctuaries' was being undermined by lax controls on the activities of government officers themselves. Buxton's view was that "a sanctuary where people are allowed to shoot is a contradiction in terms" (Buxton, 1902, p. 127). Thus in the 'Kenia Reserve' (as constituted briefly in 1899), officers had interpreted the regulations to mean they had free access to the whole of the reserve (Buxton, 1902). Such abuse was more pronounced in the Sudan, where the game reserve was regarded as an "officers' reserve". Buxton points out a little peevishly that vast areas of the Sudan, Darfur, Kordofan and land south of the Sobat for example, were declared closed to hunting by travellers, but open to officers and civil servants. It was not clear "where the mere British citizen, fond of travelling and hunting, comes in" (Buxton, 1902, p. 130). Such practices led to abuse: "game may disappear before the official uniform as well as the unprivileged traveller" (Buxton, 1902, p. 128).

Buxton's experiences in Africa gave him a clear agenda, which his 1902 book sought to set out for the reading public, and indirectly for the British government. To his concerns about reserves he added discussion about trade in ivory and rhinoceros horn (suggesting that elephants would be more valuable as load-carriers than simply as providers of ivory), and an assessment of the problem of native hunting. On that subject, he pointed out that animals were the Africans' birthright, and that "from time immemorial the destruction caused by the indigenous inhabitants has not appreciably diminished the stock" (Buxton, 1902, p. 139). However, he urged that every precaution be taken to prevent Africans acquiring "civilized weapons", and castigated the French for importing rifles into Djibouti. He noted that Pax Britannica was encouraging Kikuyu incursions to hunt elephant on the Athi Plains, and suggested that the Maasai might make good game guards (Buxton, 1902, p. 139-140).

\section{How the Society was founded}

Though derived from a desire to implement the objectives of the 1900 Convention, the foundation of the Society for the Preservation of the Wild Fauna of the Empire was also a logical extension of Buxton's views about game preservation in Africa. In 1903 it was announced that the authorities in the Sudan already wished to de-gazette the recently created White Nile Reserve situated between the White and Blue Niles and the Sobat River and replace it with a less suitable area further south on the Zeraf River. The White Nile reserve, it was proposed would be divided into two sections, one for the use of government officials and the other for the recreation of non-official visitors to the area (SPWFE, 1903).

Buxton held a series of meetings with friends and associates in his home to discuss how best to prevent this. A polite but forceful letter was written to Lord Cromer, then Governor-General of the Sudan asking him to reconsider the matter. The argument was made that ample land existed alongside the reserve to cater adequately for the recreational needs of both classes of sportsmen. Removal of the reserve would mean there was no sanctuary at all for game in the northern region, and game close to the capital would quickly be shot 
out. The alternative site, on the other hand, was of little use for game preservation. It was a considerable distance from Khartoum and the level of supervision available to the reserve would be severely reduced (SPWFE, 1903, pp. 2-3). Furthermore, because of the sudd vegetation, it was seen as probable that many species of wildlife would not find it habitable for much of the year.

This letter of opposition was given weight by the signatures of a remarkable range of aristocratic or political figures, including the Duke and Duchess of Bedford, Sir Edward Grey, Lord Avebury, the Marquis of Hamilton, the Earl of Rosebery, Sydney Buxton and Sir Henry Seton-Karr, businessmen such as brewery owner Samuel H. Whitbread, the engineer P.L. Sclater, scientists and naturalists including Oldfield Thomas, Ray Lankester and Richard Lydekker; as well as some of the most renowned colonial administrators, hunters and writers about Africa during that period such as F.C. Selous, John G. Millais, Sir John Kirk and Abel Chapman. This latter list also included Sir Harry Johnston, High Commissioner to Uganda and founder of the Sugota Reserve. Johnston himself explained that he had created the reserve as a means of gaining time after hearing that a very large armed hunting party of Somalis, rumoured to have caused much destruction in the past, were to return to the region (SPWFE, 1905c).

The first formal suggestion that this alliance might be made permanent through the formation of a society focused upon protecting the larger game animals with the Empire was given at a meeting of the letter's signatories held in the House of Commons on 30 July 1903 (SPWFE, 1903, p. 4). This was followed up in early December by a circular celebrating the success of the petition and announcing the first meeting of a small association, newly created to gather and propagate information amongst its members about "game reserves, game laws, the amount of game killed, the gradual disappearance of species, etc. throughout Africa". The second edition of the new Society's Journal in 1905 set out its aims: relying on the collective action, interest and African experience of members, they would attempt to promote the formation of game reserves or sanctuaries, help with the selection of suitable locations, and support the enforcement of deserving game laws (SPWFE, 1905a, p. 1).

\section{How the Society worked}

The SPWFE is best understood as a pressure group, whose work and influence evolved through the period. The Society made an effort from the start to position itself as an independent expert organization with the specialist knowledge necessary to assess information and influence colonial policy in Africa. As might be expected, considering their shared members, precedents for this approach can be found in the policies of the already established (Royal) African Society. During the latter Society's inaugural meeting in 1901, the keynote speech of the famous colonial administrator, explorer and zoologist Sir Harry Johnston suggested that one of the main roles of the African Society should be to "hunt over the records of other Societies and drag to light what is often overlooked - that part of their work that throws a light on African affairs - and so bring it to the notice of those who are mainly interested in Africa" (JAS, 1901, p. xiii).

Henry Seton-Karr described the role of the SPWFE in 1908 as follows: "where opportunity presents itself, we who know something of what may be going on in outlying regions wish to lose no chance of advocating, in season and out of season, and at the risk of becoming nuisances, all reasonable and effective game preservation, and on right lines" (Seton-Karr, 1908, pp. 27-28). He believed that game preservation could best be done "by Imperial Government action in the case of Crown Colonies and Protectorates; by a healthy and active public opinion working through Colonial Governments in the case of self-governing Colonies"' (Seton-Karr, 1908, p. 28). It was to these authorities that the Society primarily addressed itself during the first decade of its existence.

The Society's strengths were the personal contacts of its members, an extensive network of overseas correspondents and officials, and its ability to gain the ear of some of the leading government figures of the day, including varying degrees of access to the houses of Parliament, and the Foreign, Colonial and India Offices. Though small in size, the Society wielded considerable influence. Its early membership, like the signatories of the original letter in 1903, consisted of those who were either prominent, politically and otherwise, or those considered to be knowledgeable about Africa or African conservation, such as colonial administrators, naturalists, hunters and authors.

From the first, the SPWFE recruited as many high profile people of influence into its ranks as possible. It was declared in the first meeting of the Society that it intended to invite the senior officials and governors of all the African colonies and protectorates to become honorary members of the Society. Two years later the Society elected as Vice Presidents the prominent figures of Lords Milner, Curzon, Fry and Cromer in order to advertise itself, attract membership, and secure aid and status for the association. In 1905 the Colonial Secretary of State Alfred Lyttelton accepted an invitation to become an Honorary Member of the Society following a deputation to the Colonial Office. In the membership lists published in 1905, 27 honorary members are listed, in comparison to only 71 ordinary paying members 
(SPWFE, 1905b, pp. 2-4). In addition to senior colonial administrators and political figures from across British Africa, the list also incorporated leading figures from other parts of the world, including President Theodore Roosevelt of the United States, Prince Henry Liechtenstein in Vienna, and others from Canada, Finland, and Russia. This strategy of seeking influential members was common in London societies of the period, and like many such relationships it appears to have been mainly passive, although as described below, Lord Curzon turned out to be an obvious exception. This pattern of actively garnering influence continued well into the 1930s, as Neumann (1995) points out in his critique of the role of the Earl of Onslow (President of the Society 1926-1945, c.f. Onslow, 1944), and his successor the Duke of Devonshire.

Distinctive in their aims in the early years of the twentieth century, the founders of the Society were clearly no strangers to the use and manipulation of power and influence in the British Empire. The support of leading figures of the day was essential for the success of the Society as a body capable of affecting events in the colonies of Africa. Underneath the glittering aristocratic public face of the SPWFE however, there was also a dedicated core of workers, continuously corresponding, lobbying and sometimes arguing with administrators, game wardens, and politicians both at home and abroad. These consisted of men from a wide range of backgrounds and histories, with varying degrees of knowledge about Africa and wildlife. This became more visible as the decade wore on and the Society fought against its image as a club for rich sportsmen. It is revealing that by February 1909 Lord Crewe, the new Secretary of State for the Colonies, after listening to the arguments of a group of SPWFE representatives, took the trouble to reassure them that he himself understood the Society to be "in effect a scientific Society. It is not with you simply a question of preserving game for sportsmen, although that is a side of the matter in which many members no doubt take interest; but you are here, as I say, as a scientific Society in the main, and it is on those lines and in those interests that you wish us to help you" (SPWFE, 1909, p. 22).

Most visible as the force behind most of the Society's activities of course stood E.N. Buxton and his kin. Others however, drawn to the cause, lent their talents, knowledge and resources, consolidating and amplifying his efforts. It is clear from both the Journals and the early minutes of the Society that the literary, administrative and research contributions of Mr. (later Sir) Rhys Rhys Williams, the first honorary secretary, provided an important, although perhaps less glamorous practical element to the running of the fledging organization. In London such contributions were substantially comple- mented by very active members such as Frederick Selous, Sir Henry Seton-Karr, and the Australian adventurer and Kenyan settler W. Scoresby Routledge. Samuel $\mathrm{H}$. Whitbread of the brewing family both actively campaigned for the Society in Parliament and participated in the running of the Journal. In the very early years, Dr E.E. Austen of the Natural History Museum was perhaps the most active of the scientific advisers and representative to the Society, although other notable scientists of the day such as E.G.B. Meade Waldo, Sir Clement Hill, Oldfield Thomas and, slightly later, Dr Peter Chalmers-Mitchell, secretary of the Zoological Society of London, all became deeply involved in its activities. As already noted, outside Great Britain, the Society was able to plug into a wide network of correspondents, including Dr William T. Hornaday, Director of the New York Zoological Society. Of these however, none contributed more to the Society's sense of direction (and its journal) concerning the management and preservation of wildlife than the proliferate writer and adviser Colonel H. Stevenson-Hamilton, Warden of the game reserve that later became the Kruger National Park (Carruthers, 1995).

\section{What the Society did}

As soon as it was formed, the Society immediately began corresponding with the key figures in authority to press home warnings, complaints and requests. This included questions in the Houses of Commons and Lords on issues they deemed particularly important. During the Society's first official meeting, members resolved to send a letter questioning the British South Africa Company about its alleged plans to allow its railway construction workers to kill game for meat whilst engaged on the project. Pointing out the folly of such a course of action through reference to the lessons to be learned from the example of the Union Pacific railway and the extermination of the American Bison, the letter strongly reminded the Company of established game regulations (SPWFE, 1903, pp.7-8). A meeting soon after was arranged between the directors of the Company (including Earl Grey, who at that time was vice-chairman) and a deputation of SPWFE members. During the course of the long conversation that followed the Company explained that they would not allow the breaking of game regulations for the feeding of their workers, and also promised to contact their native commissioners asking for the best places for game sanctuaries (SPWFE, 1903, pp. 8-9).

The success of this deputation seems to have set the pattern for the Society's activities during the 1900s. The main focus of their attention was the British government. 
Between the years 1905 and 1909 the SPWFE had no less than three lengthy and fairly sympathetic meetings with different Secretaries of State for the Colonies. On each occasion, although not always satisfied with the result, they managed to make significant gains for most of the causes they were pursuing. These took the form of actual action, promises of further investigation, or the use of the influence of the colonial office in order to make suggestions or representations to self-governing colonies such as the Union of South Africa.

The issues dealt with were numerous, and the calls upon their attention rapidly grew as correspondents throughout the Empire began to recognize the Society's lobbying abilities. Initially its chief concern was the promotion of game reserves throughout Africa and the safeguarding and implementation of the 1900 Convention. As the understanding of what this might require clarified, so did their comprehension of the problems involved and the race against time that they were facing.

By 1909, the challenges facing the SPWFE had begun to multiply as the colonial situation in Africa became more complex. The early emphasis on establishing reserves quickly broadened to encompass issues such as how to handle poachers, the relative rights of natives, settlers and colonial officials, the possibilities of tourism, how to limit the smuggling of illegal animal products, and the best methods of dealing with the rising threat to wildlife brought on by growing panic concerning the tsetse fly (Glossina spp.). The Society's members had also begun to consider a wider geographical range of problems, including the Plumage Bill, seals, whaling, and the protection of elephant seals Mirounga leonina and king penguins Aptenodytes patagonicus in the Falkland Islands. It is impossible in this short paper to outline effectively the Society's handling of all these questions. Below is a summary of some of the Society's key concerns in the first decade of its existence.

\section{Game reserves}

The first deputation from the Society to the colonial office took place in 1905. Noting that many African territories had come or were coming under the control of the Colonial Office, Buxton presented a list of ideas about improvements that the Society wanted to see implemented. These included requests for adequate well guarded reserves and high ranking game officers in all territories, reasonable expenditure of public funds for game preservation, more thorough reports from overseas officials, and greater flexibility for officers on the ground to vary the list of protected "sacred" animals in their region to account for changing local events and situations. The Colonial Secretary Alfred Lyttelton pro- fessed his office unable to promise money from the Imperial Exchequer for conservation, but undertook to ensure that dispatches were sent to the African colonies about the possibility of forming carefully positioned and effectively sized game reserves throughout the protectorates. Noting his inability to intervene directly in the cases of self-governing colonies, Lyttelton also promised to press upon their administrators and others both the commercial value in maintaining game numbers and the aesthetic value of protecting beautiful places, particularly as Europe grew increasingly crowded (SPWFE, 1905c, pp. 17-18).

Over the next year, answers to the resulting dispatches were passed on to the Society by the Colonial Office with the understanding that the members would provide suggestions for protective measures in each country. To meet this request the Society prepared an extensive document detailing their recommendations (Rhys Williams, 1907), many of which were later implemented. By the time of the next deputation in 1906, however, the issue had changed somewhat from the question simply of choosing sensibly situated reserves to the need for adequate funding for their protection, and where this money should come from (SPWFE, 1907a). Thus the deputation referred to estimates quoted by then Deputy Commissioner F. J. Jackson that $£ 2,344$ was needed to protect the fauna of British East Africa (Rhys Williams, 1907; SPWFE, 1907b). Equally important was their argument that once established, reserves should be considered "sacred" and not carved up or parceled out to settlers as the process of development proceeded. As Buxton imperiously declared to Lord Elgin: "in the opinion of this Society the time when a game reserve is of the most value is when it comes into contact with civilization; when civilization begins to impinge upon the reserve, then it is of the most value, because it is then that the game is apt to be killed out, and it is then that the settler of the future will most appreciate the precaution of maintaining the reserve where it is of most use" (SPWFE, 1907a, p. 31).

Some of these issues were followed up later in the year by the MP Samuel H. Whitbread in questions to Winston Churchill, then Undersecretary of State for the Colonies in the House of Commons (SPWFE, 1907c). Little progress was reported at that stage, but it was eventually announced in 1908 that the budget for the game staff in British East Africa had been raised by the Colonial Office from $£ 300$ to the $£ 2,300$ per year asked for by the SPWFE deputation. By this point, the Society noted in an editorial that it was urgently needed due to a dramatic increase in the "white development" of East Africa (as reflected in the increase in the net railway receipts from $£ 2,639$ in 1904-1905 to $£ 76,150$ in 1906-1907 (SPWFE, 1908, p. 9). The man appointed as 
chief of this new game staff was SPWFE member (and member of the Society's deputation to the Colonial Office) Lieut-Col. J.H. Patterson, author of the famous book Man-Eaters of Tsavo and other East African Adventures (1907).

By 1909 the Society was again combating the revision of game reserve boundaries by local administrators. It warned against a policy of taking over sections of a reserve for other uses, and replacing them with other less suitable areas, unless such a decision was first countenanced by the Colonial Office itself (SPWFE, 1909). Though accepting that some reserves tended to be needlessly large, the Society took care to push the view that such changes needed to be carefully planned and discussed. Dr Chalmers Mitchell perhaps won over the Colonial Secretary most by pointing out that new land added on in replacement is not always of the same high scientific value as the old lost land, because smaller animals living in virgin untouched land tend to be destroyed when the land is cultivated. In response to these arguments Lord Crewe (then Colonial Secretary) declared that no alterations to the reserves under his authority would be made without agreement of either himself or his successors in the Colonial Office (SPWFE, 1909).

\section{The ivory trade}

A second major concern of the Society in its first decade was about trade in wildlife products. They were concerned about the export and sale of horns and skins, but their chief concern was the hunting of elephants and the trade in ivory. One of the Society's major objectives was to get agreement on a uniform rule governing and raising what they considered to be the very low minimum weight of five kilograms (11lbs) allowed for the sale of ivory. This issue was brought up repeatedly with the Colonial Office (Cd. 4472, 1909). During the interview with Lord Crewe in 1909 Rhys Williams suggested that he would like to see at the very least a $25 \mathrm{lb}$ minimum weight implemented. The Colonial Secretary responded that such a law would not be of much use without an international agreement, otherwise people would just smuggle the ivory across borders to territories that allowed lower minimums. He also noted that different protectorates had different requirements, with a much greater need for elephant protection in British East Africa for example than in the vast elephant herds of Uganda where there was a problem with keeping troublesome elephant numbers down and protecting crops (SPWFE, 1909).

On 24th February 1914 Mr. R.B. Woosnam reported to a meeting of the Society on a proposed international scheme for the protection of elephants and rhinoceros, in preparation for an upcoming conference in London on the issue. This conference was indeed held just before the outbreak of the First World. War. It decided that the export of tusks of less than $10 \mathrm{~kg}$ (approx $22 \mathrm{lbs}$ ) in weight would be prohibited, while at the same time settlers and natives might be protected against the ravages of elephants by the respective powers. However, due to the war this protocol was not ratified, and the Society had to return once more to this issue when it resumed its activities following the war (Buxton, 1921).

\section{Tsetse fly}

Perhaps the longest and most frustrating battle fought by the Society was against those who believed that African game was the main food supply for the tsetse fly, and therefore a key element in the spread of sleeping sickness, a scourge of man and beast alike. This link, greatly popularized in the middle of the first decade of the century by a sudden surge in press interest (Austen, 1907; Whitbread, 1907), resulted in calls for the extermination of the wild fauna in the worst affected parts of Africa to curtail the problem. From the moment this issue erupted, the Society found itself arguing through every means at its disposal that scientific proof should be acquired and rational systematic procedures established prior to any drastic action. Letters and articles were written to newspapers and journals, whilst members of the Society lobbied those in power both in England and in the regions in question. Through its various members, the Society quickly began to argue that, in its opinion and experience, in many areas there was no certain correlation between high population densities of game and tsetse fly. Likewise they suggested that game destruction had been by no means proven to be a solution, and they argued that it might even exacerbate the problem by narrowing the focus of targets for tsetse fly to humans and their domestic animals. Coryndon (1913), who was later Governor of Kenya in the 1920s and an important advocate of game conservation, provides an excellent overview of this debate. The Society also gave itself the task of guarding game against those seeking to use the alleged link with sleeping sickness as an excuse to ignore game licence laws or for their own profiteering. Thus in 1909 E.N. Buxton, Lord Cranworth and Sir H.H. Johnston complained to the colonial secretary about how they, once again, had worries concerning the devastation to wildlife being caused by the actions of the British South Africa Company. Rather than the possibility of the Company using game to feed its workers, this time the primary problem identified by the Society was that it had heard 
reports that the Company had thrown open entire districts to hunters, allegedly on account of tsetse fly control (SPWFE, 1909).

Arguably, the "tsetse fly menace" had some positive implications for the preservation of game, because it restricted agricultural settlement by white farmers. Perhaps unsurprisingly, considering the political nature of the problem, there is little mention of it in the early minutes, journals, and archives of the Society. This said, the Society certainly seemed to be aware of such arguments, as can be seen in a comment made in a colonial office deputation by the hunter F.C. Selous about the suitability of the tsetse fly regions in Southern Rhodesia to be made into an immense game reserve because no domestic animals or settlers could live there (SPWFE, 1905c, p. 16). It was not until 1957 however, when new experiments were making it seem feasible that the threat would soon be eradicated, that an Editorial can be found in Oryx pointing out the restrictions that tsetse fly had placed on the development of key areas in Africa, and highlighting worries about what might happen to wildlife once this constraint was no longer there (Oryx, 1957, pp. 2-3).

\section{Hunting and conservation}

From the outset, the Society had to contend with accusations from certain factions that it was merely a sportsman-hunter's lobby group. Richard Fitter and Sir Peter Scott (1978) point out that the Society was portrayed as composed of "penitent butchers": sportsmen who, having had their fill of hunting in their younger days, now wished to repent for past deeds by preserving game at the expense of others. The Society sought, rather uncomfortably, to balance an official ideology about the compatibility between properly conducted sport hunting and the preservation of large game and a desire to portray itself as a scientific minded society. Articles extolling the thrill of the hunt were commonplace in the first issues of the Society's journal, but soon began to peter out. A critical editorial in the Saturday Review on 24 November 1906 squarely placed the decreases in game at the hands of the big-game hunter and rich and irresponsible young Englishmen excitedly amassing large game bags (SPWFE, 1907d, p. 76).

Many of the key founders of the famous hunters' organization the Shikar Club were SPWFE members. These included P.B. Van der Byl, Sir Alfred Pease, F.C. Selous, and Abel Chapman. This club, formed in 1908, admitted only those who had hunted on three continents. Notably however, that same year it was resolved by the SPWFE after a discussion in a Society meeting that "an amalgamation with the Shikar Club was not advisable as the objects of the two societies were dissimilar" (Buxton, 1908). Much the same conclusion was reached, albeit in a diplomatic and somewhat bureaucratic fashion, once more in 1925 when Lord Lonsdale of the Shikar Club approached the SPWFE about a possible alliance (McKenzie, 2000). Certainly by the period of Lord Onslow's Presidency (1926-1945), the Society was far more concerned with the creation of National Parks as inviolable sanctuaries for game than about what William T. Hornaday referred to as the "cardinal principles of sportsmen" (Hornaday, 1909), although of course these still had their proponents within the Society.

The question of hunting was in fact a source of difference of opinion within the Society, both publicly and privately, almost from the beginning. Early SPWFE deputations to the Colonial Office were seldom unanimous in their opinions about how game reserves and wildlife conservation should be organized. E.N. Buxton built his model of preservation upon a belief that a share of the revenues from hunting licences could help pay for effective game protection by well-qualified staff. He argued that reserves could even create a profit and that hunting also provides an outlet for the energies of young officers, isolated in the field (SPWFE, 1907a). He felt that the "ancient hunting rights" of local native populations should be maintained, provided that only traditional weapons and techniques were used (SPWFE, 1905c, pp. 12-13). Other colleagues in the delegation to see Lord Lyttelton, such as Colonel Delme Radcliffe, begged to differ, arguing that even natives without guns should be prohibited from hunting because of the improvements made to their hunting techniques as a result of colonialism. Sir Henry Seton-Karr, big-game hunter and a founder member of the Society wrote a letter to the Society's journal, published in 1908, attempting a rebuttal criticism of the Society. He expressed the belief that the origin of the problem of diminishing game primarily lay, with certain exceptions, not with sportsmen but the "depredations" of natives and settlers (Seton-Karr, 1908, p. 27).

The idea of limiting the activities of all hunters on reserves, including Europeans, except for administrative purposes was given by other active contributors to the Society's knowledge base such Colonel StevensonHamilton. This was one of the general suggestions made by the Society in their list of recommendations to the Colonial Office in 1906 (Rhys Williams, 1907). Likewise Lord Hindlip, a member of the SPWFE and a settler in Kenya, wrote an influential article in the Society's journal arguing strongly that making exceptions with licences to privileged minorities had the effect of angering settlers and alienating them from the cause of game preservation (Hindlip, 1905). 


\section{Conclusions}

In its first decade, the Society for the Preservation of the Wild Fauna of the Empire was a powerful force lobbying for conservation within the corridors of power in Imperial London. Its network spread out into the upper reaches of British colonial government in Africa, and it drew upon both administrators and experienced game managers and hunters. It transcended the specific concerns of its founders and members with sport hunting to emphasize the importance of ordered administrative strategies for conservation across Africa, and increasingly across the Empire. That administration centred on the regulation of space, in the form of game reserves, and of people, primarily in the form of hunting regulations. Their vision of conservation helped lay the foundations for the protected area systems and the framework of hunting regulations that became the hallmarks of twentieth century conservation (Anderson \& Grove, 1987; MacKenzie, 1988). They had relatively little understanding of the ways in which Africans themselves related to wildlife, and the stereotypical view of African hunting that emerged fitted the regulation and reservation policies in place (Mackenzie, 1988).

The vision of the Society's founders of conservation was more complex than the label of "penitent butchers" implies, although the legacy of colonial thinking is none the less problematic for that (Adams \& Mulligan, 2003). In 1906 Lord Curzon, Vice President of the Society, made a plea for conservation to the Colonial Secretary that reflected a frankly imperial vision of global responsibility:

"we owe the preservation of these interesting and valuable, and sometimes disappearing, types of animal life as a duty to nature and to the world. I have seen enough of the world in travelling to know not merely that many of these types have irretrievably gone, but that owing to the scandalous neglect of our predecessors there are others which are tending to dwindle and disappear now. We are the owners of the greatest Empire in the universe; we are continually using language, which implies that we are the trustees for posterity of the Empire, but we are also the trustees for posterity of the natural contents of that Empire, and among them I do undoubtedly place these rare and interesting types of animal life to which I have referred." (SPWFE, 1907a, p. 24)

Many of the challenges faced by the founders of the SPWFE have a sharply contemporary ring. Many of their ideas about how these challenges should be met still form the basis of conservation thinking today. In the light of the long history of conservation through the twentieth century, it is interesting to reflect on the similarities between Lord Curzon's vision and that expressed by conservationists in industrialized countries a hundred years later, at the start of the twenty first century.

\section{Acknowledgements}

Research for this paper has been funded by a grant from Dr Lisbet Rausing. We would like to thank Caroline Cowan and three anonymous referees for their comments on this paper.

\section{References}

Adams, W.M. \& Mulligan, M.(eds) (2003) Decolonising Nature: Strategies for Conservation in a Post-colonial Era. Earthscan, London, UK.

Addison, W. (1991) Epping Forest: Figures in a Landscape. Robert Hale, London, UK.

Anderson, D.M. \& R.H. Grove (1987) The scramble for Eden: past, present and future in African conservation. In Conservation in Africa: People, Policies and Practice (eds D.M. Anderson \& R.H. Grove), pp. 1-12. Cambridge University Press, Cambridge, UK.

Austen, E.E. (1907) The tsetse fly as a disease carrier. Journal of the Society for the Preservation of the Wild Fauna of the Empire, III, 43-44.

Barton, G. (2002) Empire Forestry and the Origins of Environmentalism. Cambridge University Press, Cambridge, UK.

Beachey, R.W. (1967) The East African ivory trade in the nineteenth century. Journal of African History, VIII, 269-90.

Buxton, E.N. (1898) Short Stalks: Comprising Trips in Somaliland, Siani, the Eastern Desert of Egypt, and Crete, the Carpathian Mountains, and Daghestan [Second series]. E. Stanford, London, UK.

Buxton, E.N. (1902) Two African Trips: with Notes and Suggestions on Big Game Preservation. E. Stanford, London, UK.

Buxton, E.N. (1908) Minutes of a meeting of the Society for the Preservation of the Wild Fauna of the Empire held in the House of Commons on July 21st 1908. Unpublished.

Buxton, E.N. (1921) Reports of Meetings. Journal of the Society for the Preservation of the Fauna of the Empire, I, 18-23.

Buxton, E.N. (1923) Epping Forest. E. Stanford, London, UK. Carruthers, J. (1995) The Kruger National Park: a Social and Political History. University of Natal Press, Pietermaritzberg, UK.

Cd. 3189 (1906) Correspondence relating to the preservation of wild animals in Africa. Accounts and Papers, Colonies and British Possessions: Africa, LXXIX, 25-447.

Cd. 4472 (1909) Further Correspondence relating to the Preservation of Wild Animals in Africa (in continuation to cd. 3189). Accounts and Papers, Colonies and British Possessions: Colonies (Miscellaneous Reports), Colonies (General), Africa, Cyprus, LIX, 635-746.

Coryndon, R.T. (1913) Tsetse fly and big game. Journal of the Society for the Preservation of the Wild Fauna of the Empire, VI, 41-56.

Fitter, R.S.R. \& P. Scott (1978) The Penitent Butchers: the Fauna Preservation Society 1903-1978. Collins, London, UK. 
Grove, R.H. (1987) Early themes in African conservation: the Cape in the nineteenth century. In Conservation in Africa: People, Policies and Practice (eds D.M. Anderson \& R.H. Grove), pp. 21-39. Cambridge University Press, Cambridge, UK.

Grove, R.H. (1992) Origins of western environmentalism. Scientific American, 267, 42-47.

Grove, R.H. (1995) Green Imperialism: Colonial Expansion, Tropical Island Edens and the Origins of Environmentalism, 1600-1800. Cambridge University Press, Cambridge, UK.

Grove, R.H. (1997) Ecology, Climate and Empire; Colonialism and Global Environmental History 1400-1940. White Horse Press, Knapwell, UK.

Grove, R.H. (1998) Ecology, Climate Change and Empire: the Indian Legacy in Global Environmental History 1400-1940. OUP, New Delhi, UK.

Hindlip, Lord. (1905) Preservation of the fauna of British East Africa from the point of view of a settler. Journal of the Society for the Preservation of the Wild Fauna of the Empire, II, 51-57.

Hornaday, W.T. (1909) Fifteen cardinal principles affecting wild game and its pursuit. Journal of the Society for the Preservation of the Wild Fauna of the Empire, $\mathbf{V}, 56-8$.

Jacoby, K. (2001) Crimes Against Nature: Squatters, Poachers, Thieves and the Hidden History of American Conservation. University of California Press, Berkeley, USA.

JAS (1901) Inaugural Meeting. Journal of the African Society, 1, i-xviii.

McKenzie, C. (2000) The British big-game hunting tradition: masculinity and fraternalism with particular reference to the Shikar Club'. The Sports Historian, 20, 70-96.

MacKenzie, J.M. (1987) Chivalry, social Darwinism and ritualised killing: the hunting ethos in Central Africa up to 1914. In Conservation in Africa: People, Policies and Practice (eds D.M. Anderson \& R.H. Grove), pp. 41-62. Cambridge University Press, Cambridge, UK.

MacKenzie, J.M. (1988) The Empire of Nature: Hunting, Conservation and British Imperialism. University of Manchester Press, Manchester, UK.

Neumann, R.P. (1995) Ways of seeing Africa: colonial recasting of African society and landscape in Serengeti National Park. Ecumene, 2, 149-169.

Neumann, R.P. (1996) Dukes, Earls and ersatz Edens: aristocratic nature preservationists in colonial Africa. Environment and Planning D: Society and Space, 14, 79-98.

Neumann, R.P. (1997) Primitive ideas: protected area buffer zones and the politics of land in Africa. Development and Change, 28, 559-82.

Neumann, R.P. (1998) Imposing Wilderness: Struggles Over Livelihood and Nature Preservation in Africa. University of California Press, Berkeley, USA.

Onslow, R. (1944) Sixty-Three Years: Diplomacy, The Great War and Politics. Hutchinson, London, UK.

Oryx (1957) Editorial Notes. Oryx, IV, 1-4.

Patterson, J.H. (1907) Man-eaters of Tsavo and other East African Adventures. Macmillan, London, UK.

Rhys Willams, R. (1907) Recommendations of the Society sent to the Secretary of State for the Colonies in June 1906. Journal of the Society for the Preservation of the Wild Fauna of the Empire, III, 14-19.

Seton-Karr, H. (1908) The preservation of big game. Journal of the Society for the Preservation of the Wild Fauna of the Empire, IV, 26-28.
Sheail, J. (1976) Nature in Trust: the History of Nature Conservation in Britain. Blackie, Glasgow \& London, UK.

SPFE (1924) The Late Mr. E.N. Buxton. Journal of the Society for the Preservation of the Fauna of the Empire, IV, 23-4.

SPWFE (1903) Introduction. Journal of the Society for the Preservation of the Wild Fauna of the Empire, I, 23-4.

SPWFE (1905a) Origin and objects of the Society. Journal of the Society for the Preservation of the Wild Fauna of the Empire, II, 1.

SPWFE (1905b) List of Members. Journal of the Society for the Preservation of the Wild Fauna of the Empire, II, 2-4.

SPWFE (1905c) Minutes of proceedings at a deputation of the Society for the Preservation of the Wild Fauna of the Empire to the right Hon. Alfred Lyttelton (His Majesty's Secretary for the Colonies). Journal of the Society for the Preservation of the Wild Fauna of the Empire, II, 9-18.

SPWFE (1907a) Minutes of proceedings at a deputation of the Society for the Preservation of the Wild Fauna of the Empire to the right Hon. The Earl of Elgin, His Majesty's Secretary of State for the Colonies). Journal of the Society for the Preservation of the Wild Fauna of the Empire, III, 20-32.

SPWFE (1907b) Extracts from Blue Book issued November 1906. Journal of the Society for the Preservation of the Wild Fauna of the Empire, III, 33-40.

SPWFE (1907c) Question asked in the House of Commons by S.H.Whitbread, Esq., M.P., December 19 1906. Journal of the Society for the Preservation of the Wild Fauna of the Empire, III, $88-89$.

SPWFE (1907d) The dying fauna of an Empire. Journal of the Society for the Preservation of the Wild Fauna of the Empire, III, 75-77.

SPWFE (1908) Editorial note. Journal of the Society for the Preservation of the Wild Fauna of the Empire, IV, 9-10.

SPWFE (1909) Minutes of proceedings at a deputation of the Society for the Preservation of the Wild Fauna of the Empire received by the right Hon. The Earl of Crewe (Principal Secretary of State for the Colonies) at the Colonial Office. Journal of the Society for the Preservation of the Wild Fauna of the Empire, $\mathbf{V}, 11-27$.

Stevenson-Hamilton, J. (1952) South African Eden, from Sabi Game Reserve to Kruger National Park. Cassell, London, UK.

Whitbread, S.H. (1907) The Year. Journal of the Society for the Preservation of the Wild Fauna of the Empire, III, 10-13.

\section{Biographical sketches}

David Prendergast is an anthropologist, whose previous work has included studies of social welfare, kinship, religion, and inheritance systems in South Korea. His current interests concern the origins and development of pressure groups, particularly in the field of conservation.

Bill Adams is a geographer, who has carried out research on the history of conservation, on issues of society and environment in sub-Saharan Africa, and on the theory and practice of sustainable development. He is currently working on the political ecology of dryland common pool resources and the social dimensions of conservation policy. He has taught in the Department of Geography at the University of Cambridge for some years. 